\section{Mortality due to cancer of the uterine cervix in the state of Minas Gerais, Brazil, 1980- 2005: period and cohort analysis}

\author{
Mortalidade por câncer de colo de útero no Estado \\ de Minas Gerais, Brasil, 1980-2005: análise de \\ período e coorte
}

\begin{abstract}
${ }^{1}$ Centro de Tratamento de Neoplasias, Juiz de Fora, Brasil.

2 Programa de Pós-graduação em Saúde Coletiva

Universidade Federal de Juiz de Fora, Juiz de Fora, Brasil.

3 Instituto de Ciências Exatas, Universidade Federal de Juiz de Fora, Juiz de Fora, Brasil. 4 Faculdade de Medicina, Universidade Federal de Juiz de Fora, Juiz de Fora, Brasil.

Correspondence C. M. M. Alves Centro de Tratamento de Neoplasias.

Rua Espírito Santo 1115, sala 1809, Juiz de Fora, $M C$ 36016-905, Brasil. c.meurer@terra.com.br
\end{abstract}

\section{Abstract}

This study identifies the period and cohort effects on the decreasing mortality trend of cancer of the uterine cervix and of the uterus, part unspecified, in the state of Minas Gerais, Brazil, during the period 1980-2005. 11,243 cases were included. A non-parametric method was used to calculate $Z$ statistics and p-values. The cohorts were assessed one by one and also in blocks of three, so as to allow for a larger number of comparisons to be made. Greater than expected mortality reduction was observed for the cohort blocks of women born in 1913-1920; 1927-1936; 1937-1946; 1949-1956; 1963-1970; and 1969-1976. For the 1901-1908 and 1921-1928 cohort blocks a smaller than expected mortality decrease was found. As for period effect, we found a greater than expected reduction for the 2000-2001 period, in comparison with the previous one. The study suggests the existence of a significant cohort effect on mortality due to cancer of the uterine cervix in the study population, and such results have been placed in their social and political contexts.

Uterine Cervical Neoplasms; Mortality; Cohort Effect; Period Effect
Christiane Maria Meurer Alves 1,2 Ronaldo Rocha Bastos 3 Maximiliano Ribeiro Guerra ${ }^{4}$

\section{Introduction}

Cancer of the uterine cervix, hereafter referred to as cervical cancer, is considered to be theoretically avoidable by means of a long-standing screening test, the Papanicolaou smear (Pap smear), which can detect the disease at an early and curable stage 1,2 . Furthermore, its strong association with persistent infection with the human papillomavirus (HPV) is well recognized. Although this sexually transmitted infection is necessary for the development of cervical cancer, not all HPV infections will give rise to cancer 1 .

Although amenable to prevention and early detection, cervical cancer is the second most common malignancy affecting women worldwide ${ }^{3}$. In general, it is more frequent in developing countries, which account for $83 \%$ of cases worldwide, with cervical cancer representing 15\% of all female malignancies in such countries 4.

Early studies of temporal disease trends were chiefly based on graphic representations of incidence or mortality rates according to age. $\mathrm{Al}$ though graphic representations remain important for these assessments, time effects, measured through models such as linear regression, must be formally considered.

Linear regression, however, assumes that temporal trends are strongly related to age, and that such a relation has a linear character. Although age plays an important role in the etiology of many diseases, different birth cohorts may 
have different levels of exposure to certain risk factors 5 . While the age (or aging) effect means different risks associated to different age ranges, period and cohort effects try to explain changes in time-associated rates within same-age populations. The period effect represents changes in the rates associated with all age ranges, whereas the cohort effect is associated with changes in the rates in successive age ranges in successive periods 6 .

Acknowledging the importance of cervical cancer for community health, we undertook a study involving period and cohort effects on mortality due to cancer of the uterine cervix and malignant neoplasm of the uterus, part unspecified, in the state of Minas Gerais, Brazil, during the period 1980-2005.

Minas Gerais has an estimated population of 19.6 million inhabitants, representing $10 \%$ of the Brazilian population. It is the state with the largest number (853) of municipalities. Such municipalities have distinct features, with the more developed center-south, and the less developed regions of the semi-arid north and the cerrado (an area of xeromorphic vegetation akin to the savanna) to the west (Governo de Minas Gerais. http://www.mg.gov.br, accessed on 10/ May/2009).

The inclusion in this study of cases of malignant neoplasm of the uterus, part unspecified, thus defined by the International Classification of Diseases - 10th revision (ICD-10) 7, is because most cases thus codified are in fact cases of cervical cancer 8 . Because there is no consensus in the literature on the best method to undertake exploratory or confirmatory analyses of period and cohort effects, we chose the non-parametric method described by Tarone \& Chu 9 , which allows for the exploratory partition of period and cohort effects 6 .

\section{Material and methods}

Population and mortality data were collected from the Brazilian Ministry of Health database (DATASUS; http://www.datasus.gov.br), using the Demographic and Socioeconomic Health Information and the Mortality Information System (SIM), respectively. All women aged 30 to 79 years, who had, as the underlying cause of death, cervical cancer or malignant neoplasm of the uterus, part unspecified during the period 1980-2005 in the state of Minas Gerais were included.

The $9^{\text {th }}$ revision of the International Classification of Diseases (ICD-9) 10 was applied to the 1980-1995 period, and the $10^{\text {th }}$ revision (ICD-10) 7 was applied to the 1996-2005 period. The ICD-9 codes were 180 for cervical cancer (malignant neoplasm of cervix uteri) and 179 for malignant neoplasm of the uterus, part unspecified, with the ICD-10 codes being C53 and C55, respectively.

Cases were grouped in biennial ranges (30$31,32-33,34-35, \ldots, 78-79)$. Because the aforementioned databases provide population data in quinquennial age ranges, population interpolation by age and year, followed by grouping in biennial ranges, was necessary. For population interpolation we used Sprague's fifth difference formula, the most commonly used procedure, that preserves population totals in 5-year ranges 11 .

Because comparisons were made between women from the same age range, no standardization of the calculated mortality rates was made.

According to Tarone \& Chu's ${ }^{9}$ method, tables were built, with lines representing the cohorts, columns the periods, and diagonals the age ranges. In each line one cohort was compared with the next one, and in each column one period was compared with the next one. In both cases, comparisons were always made between individuals from the same age range ${ }^{6}$. The cohorts were further combined in blocks of three to allow for a larger number of comparisons to be made.

Each set of comparisons, be it to assess the period or cohort effects, has a binomial distribution, for which both the probability of trend increase and the probability of trend decrease, under the null hypothesis, of uniformity of trend, are 0.5 . The expected value is then the number of comparisons multiplied by the probability of reduction or increase, that is, the mean 12 .

For the calculations of the cohort and period effects, one by one, variance is considered as the number of comparisons (n) multiplied by the observed reduction probability (p) and by the increase probability (q), both (reduction and increase) under the null hypothesis, that is, variance $=\mathrm{n} \times \mathrm{p} \times \mathrm{q}$. Standard deviation is the positive square root of variance. $\mathrm{Z}$ statistics is calculated as the observed value minus the expected value under the null hypothesis, divided by the corresponding standard deviation 12 . In this study, the observed value was considered to be the number of reductions in the compared periods or cohorts. When the numbers of reductions are calculated for the cohorts in blocks of three, a strategy to allow for a greater number of comparisons, the calculations of variance and standard deviation must be modified. Variance is then calculated for each line, and its value is 
given by the number of comparisons added to 2 and divided by 12 , while the standard deviation is the square root of the sum of variances 12 .

$\mathrm{Z}$ statistics was thus calculated, and the $\mathrm{p}$ value obtained. Periods and cohorts with $\mathrm{p}<0.05$ were identified.

For demonstration, the continuity correction described by Tarone \& Chu ${ }^{9}$ was also made: the expected value is subtracted from the observed value, and 0.5 is subtracted from the resulting absolute number, before division by the standard deviation, in order to obtain the approximate $\mathrm{Z}$ value from the binomial discrete distribution. Furthermore, the p-value referring to the corrected $\mathrm{Z}$ was also obtained. From the data compiled for this study, tables representing 25 age ranges, 13 periods and 37 cohorts were used. Age ranges correspond to biennial intervals and the cohorts were built for four-year intervals. Cohort superimposition was observed, something that always happens with this method. However, the midpoint of the period used to define a given cohort may be considered as representative of that cohort 12 .

Preliminary analyses to assess tendency of mortality by age and period using linear regression modelling showed a general trend towards reduction in the study period 13 (Figure 1).

Based on this overall trend, the analyses presented here were undertaken, considering deviations between the observed (as reported by data) and expected mortality rates. The effects that were found to be significant, related either to period or cohort, are relative effects, reflecting the overall trend already analyzed and contained in what is generally referred to as the changing age structure of mortality.

\section{Results}

Of the 11,243 cases included, 6,123 (54.46\%) were of cervical cancer and 5,120 (45.54\%) were of malignant neoplasm of the uterus, part unspecified.

On one by one cohort comparison, a smaller than expected reduction for the 1923-1926 birth cohort was observed, with $(Z=-2.1)$, compared to the previous cohort (1921-1924). There was a greater than expected reduction for the 1917$1920(\mathrm{Z}=2.1), 1931-1934(\mathrm{Z}=2.3)$ and 1967-1970 $(\mathrm{Z}=2)$ cohorts, compared with the previous ones, 1915-1918, 1929-1932 e 1965-1968, respectively (Table 1).

The assessment of birth cohorts in blocks of three revealed smaller than expected reduction for the blocks of women from the 1901-1908 ( $\mathrm{Z}=$ -1.96) and the 1921-1928 $(Z=-2.33)$ cohorts.
Greater than expected reduction was found for the 1913-1920 ( $Z=1.98) ; 1927-1936(Z=2.62)$; $1937-1946(Z=1.96) ; 1949-1956(Z=2.33)$; 1963 $1970(Z=2.4)$ and $1969-1976(Z=1.9)$ blocks (Table 2).

Note that the trends highlighted by this exploratory analysis do not undergo relevant variation when blocks of three are used.

For the period effect, there was greater than expected reduction for the 2000-2001 period, when compared to the previous one (1998-1999), with $\mathrm{Z}=3$ (Table 1 ).

Both tables show changes in $\mathrm{Z}$ values and their corresponding significances produced by continuity correction. As this study is of an exploratory nature, where the distance of the calculated statistic from zero is considered a trend indicator, we discussed the results of the uncorrected $\mathrm{Z}$ statistic.

\section{Discussion and conclusion}

Tarone \& Chu's ${ }^{9}$ non-parametric test aims to identify changes in the inclination of the linear risk trend in successive birth cohorts or along the calendar-period, as it assumes that age-specific rates will remain constant in the absence of any secular change in the disease risk, which justifies the fact that the procedure is based on the comparison of age-specific rates.

A smaller than expected reduction of mortality due to cervical cancer was observed for the 1901-1908 cohort block. These cohorts comprise women who are likely to have initiated their sexual lives in the 1920s, a historical period shaped by important socioeconomic changes in Brazil, such as: immigration, urbanization and the onset of industrialization. Furthermore, cancer-related policies were just beginning, with cancer being then seen as a communicable disease like tuberculosis 14 . The entry of new HPV strains with immigration, lack of knowledge about the disease, and absence of preventive policies then, may all have contributed to the higher mortality of women from those cohorts.

Another cohort block where smaller than expected mortality reduction was observed was the 1921-1928 one, which comprises women who were in their 20's at the time of the Second World War. In spite of the geographic distance from the involved areas, and of the small part Brazil took in the conflict 15 , the introduction of new HPV strains may have contributed to this finding in the study population. The same was observed by Tarone \& Chu 16 , in a study on the age-periodcohort effect on mortality due to cervical cancer in the United States. The authors reported in- 
Temporal trend of mortality due to cancer of the uterine cervix and malignant neoplasm of the uterus, part unspecified, during the period 1980-2005, for the state of Minas Gerais, Brazil.

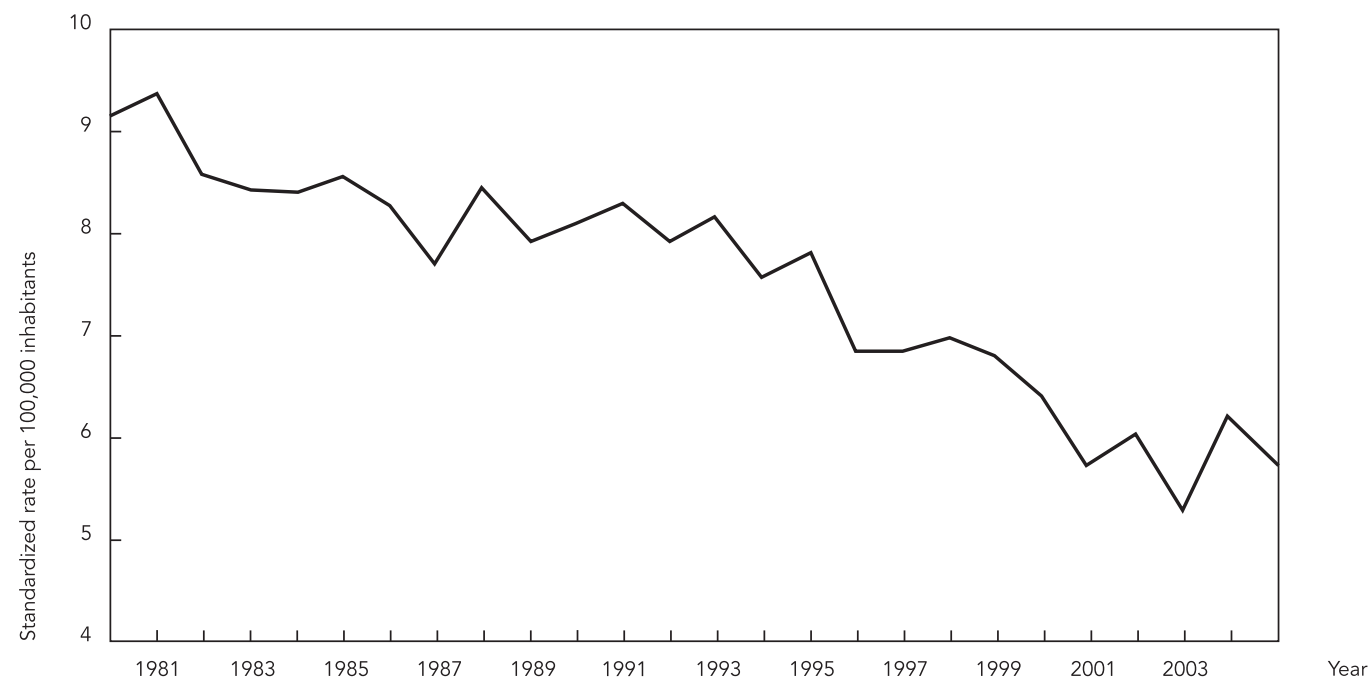

creased mortality in the 1930 cohort (1924-1934 interval), which might have been related to the introduction of new HPV strains after the Second World War.

There was a greater than expected mortality reduction in the 1913-1920 period. Women from this cohort lived during a conservative political period in Brazil known as the New State (19301945), where there were strong links between State and Church, including compulsory religious teaching in public schools 15 . This conservative background, against which these women lived their late teens and young adulthood, may have, to a certain extent, contributed to a reduction in mortality. Furthermore, these women witnessed the beginning of national initiatives targeting cervical cancer, such as the creation of the National Cancer Service (1941); introduction of colposcopy and colpocytology (1945/1946); creation of the first outpatient facility for the early diagnosis of gynecologic cancer at the Hospital Moncorvo Filho, Rio de Janeiro (1948); organization of colposcopy courses (1949) taught by its own inventor, Dr. Hinselman; and radio broadcasts (1948) highlighting the importance of the gynecologic examination 14 . Therefore, the measures implemented in Brazil at that time may have contributed to the mortality reduction observed for this cohort in Minas Gerais. Accordingly, a 2006 study related the reduced mortality due to cervical cancer observed in the 1920 birth cohort in Hong Kong to easier access to preventive examinations through time 17 .

Another mortality reduction was observed in the 1927-1936 cohort block. It is noteworthy that the early 1950s were marked by conservatism and intense influence of the Church on Brazilian society 15 . The health field was impacted by a number of events including: the creation of the Ministry of Health (1953); the Luíza Gomes de Lemos Research Center of the Social Pioneers Foundation, in 1956, with the first course for the formation of technicians in cytology in Brazil; and the National Cancer Institute, in 1961, important not only for care, but also for human resource training and the development of cancer basic research 14 .

The 1937-1946 cohort block also showed a reduction in mortality, which may be partly explained by the fact that women from this cohort were exposed to a greater concern about cervical cancer, which chiefly happened from 1963 onwards, with the creation and strengthening of a more permanent health services structure, over the campaign-based strategy which until then predominated 14 .

There was mortality reduction among the women from the 1949-1956 birth cohort, com- 
Table 1

Cervical cancer and uterus not otherwise specified, cohort and period one by one, from 1980-2005. Minas Gerais State, Brazil.

\begin{tabular}{|c|c|c|c|c|c|c|c|c|c|c|}
\hline & 1980-1981 & $1982-1983$ & 1984-1988 & 1986-1987 & 1988-1989 & 1990-1991 & $1992-1993$ & 1994-1995 & 1996-1997 & 1998-1999 \\
\hline 1901-1904 & 32.91 & & & & & & & & & \\
\hline 1903-1906 & 57.35 & 44.01 & & & & & & & & \\
\hline 1905-1908 & 67.59 & 60.38 & 63.94 & & & & & & & \\
\hline 1907-1910 & 39.47 & 65.43 & 44.41 & 33.56 & & & & & & \\
\hline 1909-1912 & 45.88 & 33.05 & 47.19 & 47.90 & 60.85 & & & & & \\
\hline 1911-1914 & 36.43 & 42.11 & 49.19 & 55.60 & 52.65 & 34.63 & & & & \\
\hline 1913-1916 & 33.23 & 43.31 & 40.87 & 41.56 & 52.20 & 42.56 & 49.57 & & & \\
\hline 1915-1918 & 27.04 & 36.63 & 34.19 & 37.59 & 47.55 & 50.74 & 49.69 & 55.62 & & \\
\hline 1917-1920 & 37.35 & 38.61 & 29.04 & 26.88 & 31.55 & 37.56 & 48.57 & 38.65 & 35.39 & \\
\hline 1919-1922 & 32.34 & 23.07 & 28.66 & 22.37 & 39.56 & 37.11 & 39.17 & 64.53 & 40.39 & 50.62 \\
\hline 1921-1924 & 24.09 & 34.10 & 17.62 & 24.53 & 25.09 & 34.46 & 33.38 & 37.73 & 33.48 & 31.66 \\
\hline 1923-1926 & 32.34 & 24.98 & 34.20 & 35.51 & 24.45 & 34.25 & 37.76 & 35.23 & 24.14 & 40.98 \\
\hline $1925-1928$ & 20.70 & 27.55 & 32.70 & 29.24 & 36.45 & 30.98 & 36.31 & 30.25 & 32.52 & 34.99 \\
\hline 1927-1930 & 17.95 & 19.00 & 28.64 & 28.05 & 20.23 & 32.48 & 30.97 & 33.18 & 32.36 & 33.41 \\
\hline 1929-1932 & 28.01 & 29.17 & 34.29 & 30.17 & 26.84 & 24.05 & 27.73 & 28.69 & 34.61 & 30.35 \\
\hline 1931-1934 & 19.95 & 14.17 & 24.43 & 22.72 & 19.47 & 28.95 & 18.28 & 26.73 & 23.82 & 28.44 \\
\hline 1933-1936 & 23.38 & 14.42 & 18.27 & 20.08 & 23.13 & 30.86 & 20.23 & 24.33 & 17.94 & 23.87 \\
\hline 1935-1938 & 16.83 & 19.66 & 13.33 & 22.95 & 23.47 & 22.56 & 24.41 & 24.89 & 18.81 & 24.28 \\
\hline $1937-1940$ & 13.21 & 9.21 & 14.99 & 11.49 & 23.42 & 18.63 & 22.66 & 26.38 & 22.83 & 27.13 \\
\hline 1939-1942 & 11.48 & 10.34 & 12.97 & 14.72 & 19.23 & 18.83 & 21.43 & 22.75 & 15.81 & 25.99 \\
\hline 1941-1944 & 6.78 & 6.97 & 8.77 & 8.38 & 19.45 & 14.96 & 25.42 & 16.44 & 14.49 & 21.06 \\
\hline 1943-1946 & 8.20 & 6.63 & 7.54 & 14.06 & 13.97 & 16.12 & 14.37 & 14.72 & 17.47 & 15.39 \\
\hline $1945-1948$ & 3.23 & 4.08 & 8.32 & 6.82 & 8.01 & 11.74 & 13.32 & 16.09 & 16.85 & 17.46 \\
\hline $1947-1950$ & 3.04 & 3.56 & 4.35 & 4.62 & 6.19 & 14.75 & 9.94 & 12.17 & 18.43 & 17.17 \\
\hline 1949-1952 & 1.96 & 4.47 & 3.56 & 5.93 & 8.15 & 7.02 & 12.03 & 12.73 & 13.22 & 11.57 \\
\hline 1951-1954 & & 2.33 & 3.86 & 4.31 & 3.28 & 5.65 & 7.77 & 6.41 & 12.24 & 11.73 \\
\hline $1953-1956$ & & & 0.96 & 2.39 & 4.98 & 2.61 & 6.13 & 7.43 & 9.42 & 9.02 \\
\hline 1955-1958 & & & & 2.46 & 2.69 & 3.57 & 6.13 & 4.60 & 7.78 & 11.36 \\
\hline $1957-1960$ & & & & & 0.84 & 4.42 & 4.90 & 3.58 & 7.48 & 8.92 \\
\hline 1959-1962 & & & & & & 2.58 & 4.23 & 2.94 & 4.02 & 4.58 \\
\hline 1961-1964 & & & & & & & 1.91 & 2.58 & 3.05 & 3.53 \\
\hline $1963-1966$ & & & & & & & & 2.06 & 2.00 & 3.15 \\
\hline $1965-1968$ & & & & & & & & & 2.52 & 3.37 \\
\hline $1967-1970$ & & & & & & & & & & 1.58 \\
\hline \multicolumn{11}{|l|}{ 1969-1972 } \\
\hline \multicolumn{11}{|l|}{$1971-1974$} \\
\hline \multicolumn{11}{|l|}{ 1973-1976 } \\
\hline $\begin{array}{l}\text { Expected } \\
\text { number }\end{array}$ & & 12.5 & 12.5 & 12.5 & 12.5 & 12.5 & 12.5 & 12.5 & 12.5 & 12.5 \\
\hline Decrease & & 14 & 14 & 16 & 10 & 15 & 13 & 15 & 12 & 10 \\
\hline$Z$ test & & 0.60 & 0.60 & 1.40 & -1.00 & 1.00 & 0.20 & 1.00 & -0.20 & -1.00 \\
\hline$p$-value & & 0.55 & 0.55 & 0.16 & 0.32 & 0.32 & 0.84 & 0.32 & 0.84 & 0.32 \\
\hline Z corrected & & 0.40 & 0.40 & 1.20 & -0.80 & 0.80 & 0.00 & 0.80 & 0.00 & -0.80 \\
\hline$p$-value & & 0.69 & 0.69 & 0.23 & 0.42 & 0.42 & 1.00 & 0.42 & 1.00 & 0.42 \\
\hline corrected & & & & & & & & & & \\
\hline
\end{tabular}

(continues) 


2000-2001 2002-2003 2004-2005 Decrease Expect $\quad Z \quad$ p-value $\quad Z$ corrected $\begin{gathered}\text { p-value } \\ \text { corrected }\end{gathered}$

1901-1904

1903-1906

1905-1908

1907-1910

1909-1912

1911-1914

1913-1916

1915-1918

1917-1920

1919-1922

1921-1924

1923-1926

1925-1928

1927-1930

1929-1932

1931-1934

1933-1936

1935-1938

1937-1940

1939-1942

1941-1944

1943-1946

1945-1948

1947-1950

1949-1952

1951-1954

1953-1956

1955-1958

1957-1960

1959-1962

1961-1964

1963-1966

1965-1968

1967-1970

1969-1972

1971-1974

1973-1976

Expected number

Decrease

$Z$ test

$\mathrm{p}$-value

Z corrected

$\mathrm{p}$-value corrected

(20)

31.49

32.41

32.18

30.02

32.56

31.08

23.29

20.77

21.31

22.81

16.28

18.78

13.55

15.26

13.04

12.21

10.21

8.01

9.99

5.75

5.59

3.58

2.67

1.77

1.24

12.5

20

3.00

0.00

2.80

0.01
52.31

38.09

37.62

36.18

21.92

23.14

29.16

25.17

14.96

21.47

11.03

19.14

14.99

12.06

10.71

11.65

8.75

7.15

7.47

6.00

4.73

3.14

1.56

2.07

1.21

12.5

15

1.00

0.32

0.80

0.42

(1)

0

0
0

3

2

(

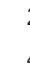

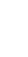

7

7

3

8

8
2

40.55

47.44

28.14

35.99

33.67

30.28

25.83

24.98

23.40

18.81

21.07

17.14

10.51

15.73

10.12

12.60

9.91

9.10

8.25

5.07

4.23

2.88

2.52

1.17

1.17

12.5

14

0.60

0.55

0.40

0.69

$\begin{array}{lll}0.32 & 0.00 & 1.00\end{array}$

$\begin{array}{lll}0.16 & -0.71 & 0.48\end{array}$

$\begin{array}{lll}0.08 & 1.15 & 0.25\end{array}$

$\begin{array}{lll}1.00 & -0.50 & 0.62\end{array}$

$\begin{array}{lll}0.65 & 0.00 \quad 1.00\end{array}$

$\begin{array}{lll}0.41 & 0.41 & 0.68\end{array}$

$\begin{array}{lll}0.71 & 0.00 & 1.00\end{array}$

$\begin{array}{lll}0.03 & 1.77 & 0.08\end{array}$

$\begin{array}{lll}0.32 & -0.67 & 0.51\end{array}$

$\begin{array}{lll}0.06 & 1.58 & 0.11\end{array}$

$\begin{array}{lll}0.03 & -1.81 & 0.07\end{array}$

$\begin{array}{lll}1.00 & -0.29 & 0.77\end{array}$

$\begin{array}{lll}0.56 & 0.29 & 0.77\end{array}$

$\begin{array}{lll}1.00 & -0.29 & 0.77\end{array}$

$\begin{array}{lll}0.02 & 2.02 & 0.04\end{array}$

$\begin{array}{lll}1.00 & -0.29 & 0.77\end{array}$

$\begin{array}{lll}1.00 & -0.29 & 0.77\end{array}$

$\begin{array}{lll}0.56 & 0.29 & 0.77\end{array}$

$\begin{array}{lll}0.56 & 0.29 & 0.77\end{array}$

$\begin{array}{lll}0.25 & 0.87 & 0.39\end{array}$

$\begin{array}{lll}0.56 & 0.29 & 0.77\end{array}$

$\begin{array}{lll}0.56 & 0.29 & 0.77\end{array}$

$\begin{array}{lll}1.00 & -0.29 & 0.77\end{array}$

$\begin{array}{lll}1.00 & -0.29 & 0.77\end{array}$

$\begin{array}{lll}0.56 & 0.29 & 0.77\end{array}$

$\begin{array}{lll}0.13 & 1.21 & 0.23\end{array}$

$\begin{array}{lll}0.53 & -0.32 & 0.75\end{array}$

$\begin{array}{lll}0.74 & 0.00 & 1.00\end{array}$

$\begin{array}{lll}0.48 & 0.35 & 0.72\end{array}$

$\begin{array}{lll}0.71 & 0.00 & 1.00\end{array}$

$\begin{array}{lll}1.00 & -0.41 & 0.68\end{array}$

$\begin{array}{lll}0.65 & 0.00 & 1.00\end{array}$

$\begin{array}{lll}0.05 & 1.50 & 0.13\end{array}$

$\begin{array}{lll}0.56 & 0.00 & 1.00\end{array}$

$\begin{array}{lll}0.16 & 0.71 & 0.48\end{array}$

$\begin{array}{lll}0.32 & 0.00 & 1.00\end{array}$ 
Table 2

Cervical cancer and uterus not otherwise specified, cohort blocks size three, from 1980-2005. Minas Gerais State, Brazil.

\section{$1980-1981 \quad 1982-1983 \quad 1984-1985 \quad 1986-1987 \quad 1988-1989 \quad 1990-1991 \quad 1992-1993 \quad 1994-1995 \quad 1996-1997 \quad 1998-1999$}

\begin{tabular}{|c|c|c|c|c|c|c|c|c|c|c|}
\hline 1901-1904 & 32.91 & & & & & & & & & \\
\hline 1903-1906 & 57.35 & 44.01 & & & & & & & & \\
\hline $1905-1908$ & 67.59 & 60.38 & 63.94 & & & & & & & \\
\hline 1907-1910 & 39.47 & 65.43 & 44.41 & 33.56 & & & & & & \\
\hline 1909-1912 & 45.88 & 33.05 & 47.19 & 47.90 & 60.85 & & & & & \\
\hline 1911-1914 & 36.43 & 42.11 & 49.19 & 55.60 & 52.65 & 34.63 & & & & \\
\hline 1913-1916 & 33.23 & 43.31 & 40.87 & 41.56 & 52.20 & 42.56 & 49.57 & & & \\
\hline 1915-1918 & 27.04 & 36.63 & 34.19 & 37.59 & 47.55 & 50.74 & 49.69 & 55.62 & & \\
\hline 1917-1920 & 37.35 & 38.61 & 29.04 & 26.88 & 31.55 & 37.56 & 48.57 & 38.65 & 35.39 & \\
\hline 1919-1922 & 32.34 & 23.07 & 28.66 & 22.37 & 39.56 & 37.11 & 39.17 & 64.53 & 40.39 & 50.62 \\
\hline 1921-1924 & 24.09 & 34.10 & 17.62 & 24.53 & 25.09 & 34.46 & 33.38 & 37.73 & 33.48 & 31.66 \\
\hline 1923-1926 & 32.34 & 24.98 & 34.20 & 35.51 & 24.45 & 34.25 & 37.76 & 35.23 & 24.14 & 40.98 \\
\hline $1925-1928$ & 20.70 & 27.55 & 32.70 & 29.24 & 36.45 & 30.98 & 36.31 & 30.25 & 32.52 & 34.99 \\
\hline $1927-1930$ & 17.95 & 19.00 & 28.64 & 28.05 & 20.23 & 32.48 & 30.97 & 33.18 & 32.36 & 33.41 \\
\hline 1929-1932 & 28.01 & 29.17 & 34.29 & 30.17 & 26.84 & 24.05 & 27.73 & 28.69 & 34.61 & 30.35 \\
\hline 1931-1934 & 19.95 & 14.17 & 24.43 & 22.72 & 19.47 & 28.95 & 18.28 & 26.73 & 23.82 & 28.44 \\
\hline 1933-1936 & 23.38 & 14.42 & 18.27 & 20.08 & 23.13 & 30.86 & 20.23 & 24.33 & 17.94 & 23.87 \\
\hline 1935-1938 & 16.83 & 19.66 & 13.33 & 22.95 & 23.47 & 22.56 & 24.41 & 24.89 & 18.81 & 24.28 \\
\hline 1937-1940 & 13.21 & 9.21 & 14.99 & 11.49 & 23.42 & 18.63 & 22.66 & 26.38 & 22.83 & 27.13 \\
\hline 1939-1942 & 11.48 & 10.34 & 12.97 & 14.72 & 19.23 & 18.83 & 21.43 & 22.75 & 15.81 & 25.99 \\
\hline 1941-1944 & 6.78 & 6.97 & 8.77 & 8.38 & 19.45 & 14.96 & 25.42 & 16.44 & 14.49 & 21.06 \\
\hline 1943-1946 & 8.20 & 6.63 & 7.54 & 14.06 & 13.97 & 16.12 & 14.37 & 14.72 & 17.47 & 15.39 \\
\hline 1945-1948 & 3.23 & 4.08 & 8.32 & 6.82 & 8.01 & 11.74 & 13.32 & 16.09 & 16.85 & 17.46 \\
\hline $1947-1950$ & 3.04 & 3.56 & 4.35 & 4.62 & 6.19 & 14.75 & 9.94 & 12.17 & 18.43 & 17.17 \\
\hline 1949-1952 & 1.96 & 4.47 & 3.56 & 5.93 & 8.15 & 7.02 & 12.03 & 12.73 & 13.22 & 11.57 \\
\hline 1951-1954 & & 2.33 & 3.86 & 4.31 & 3.28 & 5.65 & 7.77 & 6.41 & 12.24 & 11.73 \\
\hline 1953-1956 & & & 0.96 & 2.39 & 4.98 & 2.61 & 6.13 & 7.43 & 9.42 & 9.02 \\
\hline 1955-1958 & & & & 2.46 & 2.69 & 3.57 & 6.13 & 4.60 & 7.78 & 11.36 \\
\hline 1957-1960 & & & & & 0.84 & 4.42 & 4.90 & 3.58 & 7.48 & 8.92 \\
\hline 1959-1962 & & & & & & 2.58 & 4.23 & 2.94 & 4.02 & 4.58 \\
\hline 1961-1964 & & & & & & & 1.91 & 2.58 & 3.05 & 3.53 \\
\hline 1963-1966 & & & & & & & & 2.06 & 2.00 & 3.15 \\
\hline 1965-1968 & & & & & & & & & 2.52 & 3.37 \\
\hline 1967-1970 & & & & & & & & & & 1.58 \\
\hline \multicolumn{11}{|l|}{ 1969-1972 } \\
\hline \multicolumn{11}{|l|}{ 1971-1974 } \\
\hline $1973-1976$ & & & & & & & & & & \\
\hline
\end{tabular}

(continues) 


\subsection{1}

1929-1932

32.18

30.02

38.09

37.62

40.55

1931-1934

32.56

36.18

47.44

28.14

1933-1936

31.08

21.92

35.99

1935-1938

23.29

23.14

33.67

1937-1940

20.77

29.16

25.17

1939-1942

21.31

1941-1944

22.81

14.96

1943-1946

1945-1948

1947-1950

1949-1952

1951-1954

1953-1956

1955-1958

1957-1960

1959-1962

1961-1964

1963-1966

1965-1968

1967-1970

1969-1972

1971-1974

16.28

21.47

18.78

11.03

19.14

14.99

15.26

13.04

12.06

10.71

11.65

10.21

8.75

9.99

7.15

5.75

5.59

7.47

6.00

4.73

3.14

1.56

2.07

1.21

1973-1976
2.67

1.24

\begin{tabular}{|c|c|}
\hline 1.5 & -1.96 \\
\hline 2.5 & 0.58 \\
\hline 3.5 & 1.57 \\
\hline 4.5 & -0.48 \\
\hline 5.5 & 0.45 \\
\hline 6.5 & 0.42 \\
\hline 7.5 & 1.99 \\
\hline 8.5 & 1.13 \\
\hline 9.5 & 1.08 \\
\hline 10.5 & -0.35 \\
\hline 11.5 & -2.33 \\
\hline 12 & 0.65 \\
\hline 12 & 0.65 \\
\hline 12 & 2.62 \\
\hline 12 & 2.62 \\
\hline 12 & 0.00 \\
\hline 12 & 0.65 \\
\hline 12 & 1.31 \\
\hline 12 & 1.96 \\
\hline 12 & 1.96 \\
\hline 12 & 1.31 \\
\hline 12 & 0.65 \\
\hline 12 & 0.00 \\
\hline 12 & 0.65 \\
\hline 11.5 & 2.33 \\
\hline 10.5 & 1.04 \\
\hline 9.5 & -1.08 \\
\hline 8.5 & 0.38 \\
\hline 7.5 & 0.40 \\
\hline 6.5 & -0.42 \\
\hline 5.5 & 0.45 \\
\hline 4.5 & 2.40 \\
\hline 3.5 & 1.57 \\
\hline 2.5 & 0.58 \\
\hline 1.5 & 1.96 \\
\hline
\end{tabular}

$-1.31$

0.00

1.04

0.00

0.00

0.00

1.59

0.76

0.72

0.00

$-2.00$

0.33

0.33

2.29

2.29

$-0.33$

0.33

0.98

1.64

1.64

0.98

0.33

$-0.33$

0.33

2.00

0.69

$-0.72$

0.00

0.00

0.00

0.00

1.92

1.04

0.00

1.31
0.19

1.00

0.30

1.00

1.00

1.00

0.11

0.45

0.47

1.00

0.05

0.74

0.74

0.02

0.02

0.74

0.74

0.33

0.10

0.10

0.33

0.74

0.74

0.74

0.05

0.49

0.47

1.00

1.00

1.00

1.00

0.05

0.30

1.00

0.19 prising those becoming sexually active (around 20 years of age) at the onset of political repression and military dictatorship in Brazil. These women also experienced the National Campaign Against Cancer, institutionalized in 1968; the birth of the worldwide Primary Care principles in the late 1970s; the creation of the National Program Against Cancer, chiefly targeting radiotherapy and early diagnosis of cervical cancer (1972-1975) 12; the birth of the women's modern movement in Brazil, in 1975 18, and the coming of age of the Motherhood-Childhood Program, which had gynecologic cancer as one of its priorities ${ }^{19}$. Furthermore, these women were around 40 years of age when the Brazilian Unified National Health System (SUS) and the Program Against Cervical Cancer (Viva-Mulher) were created 20 . As a consequence, the lower mortality observed among these women may have been due to easier access to diagnosis and treatment, as well as a greater awareness of female rights and cancer-targeted campaigns. 
There was another mortality reduction for the 1963-1970 cohort block, comprising women who witnessed the end of the Brazilian military dictatorship. It is noteworthy that the opposite happened in Spain, that is, there was increased mortality due to cervical cancer among women born after the 1939-1948 cohort, a finding that was related to the end of Franco's dictatorship in 197521 . Notwithstanding, the end of the Brazilian dictatorship came as the result of political inertia on the part of the military government itself 22 . During this period, there was easier access to prevention and diagnosis, through the creation of the Comprehensive Program of Women's Health Care (PAISM), which introduced the colpocytologic examination in the routine of the gynecology examination (1984) 14; the birth of Pro-Onco, in 1986, that among other things created the Expansion of Prevention and Control of Uterine Cancer Program 14; and the beginning of the SUS 22.

Women from the 1969-1976 cohorts, for whom another mortality reduction was observed, witnessed SUS implantation and universal access to health. They also became aware of the relationship between the disease and HPV infection, being also exposed to the massive $\mathrm{Vi}$ va-Mulher campaigns, targeted at cervical and breast cancer 23 .

The 2000-2001 showed a greater reduction in mortality than the previous one, that is 19981999. This period effect may be related to the creation of the National Program Against Cervical Cancer (PNCCC), in 1998 24. The context saw an $81 \%$ increase in the annual number of cytologic examinations performed in the SUS in the period $1995-2003$, with a $112.6 \%$ increase for the southeastern region alone 23 . This fact, coupled with the aggressive campaign targeting cervical cancer in 1998, may be associated to the period effect found.

Our study has limitations though. We used secondary data, more prone to problems with collection and processing, and $46.58 \%$ of our cases were classified as malignant neoplasm of the uterus, part unspecified. On the other hand, the proportion of female deaths recorded as ill-defined causes in the state of Minas Gerais has been reduced 25 in the period under study (19.37\% in 1980; $11.26 \%$ in 2005) (DATASUS. http://www. datasus.gov.br, accessed on 17/Jan/2009). Besides, reports of cancer as cause of death are generally recognized as well registered 26 . Both aspects make mortality data more reliable. Therefore, the results reported here tend to be more reliable as data become more reliable, in that the aforementioned effects are relative to the overall mortality trend represented by increasingly accurate data collected throughout a 26-year span.

Furthermore, although the focus of the method used was on exploratory analysis, it does not provide the quantification of the influence of the effects observed. There is also a limitation due to the multiple comparisons that are inherent to the method, and whose control, classically undertaken through the too conservative Bonferroni method, still seems elusive 27 . It must be taken into account, though, that the absence of corrections for multiple comparisons may lead to type 1 error, when statistical significance for a chosen significance level is thought to have been found, even when there is actually no statistical difference 28

In spite of these limitations, this exploratory study suggests the existence of cohort effects on the mortality due to cervical cancer in the study population. It also highlights the importance of systematic approaches to the analysis of the mortality trends of several diseases. There is a scarcity of publications about cancer mortality trends focusing on age-period-cohort effects involving populations from developing countries based on the method we used. An adjusted age-periodcohort model approach to the data would be the next step to confronting the results found. 


\section{Resumo}

Buscou-se identificar os efeitos período e coorte na tendência de mortalidade por câncer de colo de útero e útero porção não especificada, no Estado de Minas Gerais, Brasil, no período de 1980-2005. Foram incluídos 11.243 casos. Utilizou-se método não paramétrico para o cálculo da estatística $Z$ e valor de $p$. As coortes foram avaliadas uma a uma e em blocos de três, para possibilitar o aumento do número de comparações. Observou-se redução da mortalidade maior que a esperada para os blocos de coortes das mulheres nascidas de 1913-1920; 1927-1936; 1937-1946; 19491956; 1963-1970; 1969-1976. Para os blocos de coortes de 1901-1908 e 1921-1928, encontrou-se redução da mortalidade menor que a esperada. No que se refere ao efeito período, foi evidenciada uma redução maior que a esperada para o período de 2000-2001, quando comparado ao anterior. O estudo sugere a existência do efeito coorte significativo sobre a mortalidade por câncer de colo de útero na população estudada, os resultados foram confrontados com o contexto social e político.

Neoplasias do Colo do Útero; Mortalidade; Efeito de Coortes; Efeito Período

\section{References}

1. Rydström C, Törnberg S. Cervical cancer incidence and mortality in the best and worst of worlds. Scand J Public Health 2006; 34:295-303.

2. Schiffman MH, Hildesheim A. Cervical cancer. In: Schottenfeld D, Fraumeni Jr. JF, editors. Cancer epidemiology and prevention. $2^{\text {nd }}$ Ed. New York: Oxford University Press; 1996. p. 1090-116.

3. World Health Organization. Comprehensive cervical cancer control: a guide to essential practice. Geneva: World Health Organization; 2006.

4. Parkin DM, Bray F, Ferlay J, Pisani P. Global cancer statistics, 2002. CA Cancer J Clin 2005; 55:74-108.

5. Holford TR. Understanding the effects of age, period and cohort on incidence and mortality rates. Annu Rev Public Health 1991; 12:425-57.

6. Robertson C, Gandini S, Boyle P. Age-period-cohort models: a comparative study of available methodologies. J Clin Epidemiol 1999; 52:569-83.

7. Organização Mundial da Saúde. Manual de classificação estatística internacional de doenças e problemas relacionados à saúde, 10a revisão. São Paulo: Centro Colaborador da OMS para a Classificação de Doenças em Português; 1995.

\section{Contributors}

C. M. M. Alves participated in the data collection, analysis and article write up. R. R. Bastos and M. R. Guerra collaborated in the analysis, write up and critical revision of the article.
8. Derossi AS, Paim JS, Aquino E, Silva LMV. Evolução da mortalidade e anos potenciais de vida perdidos por câncer cérvico-uterino em Salvador (BA), 1979-1997. Rev Bras Cancerol 2001; 47:163-70.

9. Tarone RE, Chu KC. Nonparametric evaluation of birth cohort trends in disease rates. J Epidemiol Biostat 2000; 5:177-91.

10. Organização Mundial da Saúde. Manual de classificação estatística internacional de doenças, lesões e causas de óbitos - nona conferência de revisão. São Paulo: Centro Brasileiro de Classificação de Doenças em Português; 1985.

11. Givisiez GHN. Introdução a métodos de estimativas e interpolações populacionais. In: Rios-Neto ELG, Riani JLR, organizadores. Introdução à demografia da educação. http://www.abep.nepo. unicamp.br/docs/outraspub/demoedu/partelca p2p45a70.pdf (accessed on 12/Feb/2009).

12 Tarone RE, Chu KC. Implications of birth cohort patterns in interpreting trends in breast cancer rates. J Natl Cancer Inst 1992; 84:1402-10. 
13. Alves CMM, Guerra MR, Bastos RR. Tendência de mortalidade por câncer de colo de útero para o Estado de Minas Gerais, Brasil, 1980-2005. Cad Saúde Pública 2009; 25:1693-700.

14. Bodstein RCA, Fonseca CMO, Klein LE, Albuquerque MBM, Fernandes TMD. História e saúde pública: a política de controle do câncer no Brasil. Rio de Janeiro: Programa de Educação Continuada, Escola Nacional de Saúde Pública; 1987.

15. Fausto B. O Estado Getulista (1930-1945). In: Fausto B, organizador. História do Brasil. São Paulo: Edusp; 2008. p. 329-94.

16. Tarone RE, Chu KC. Age-period-cohort analyses of breast-, ovarian-, endometrial- and cervicalcancer mortality rates for Caucasian women in the USA. J Epidemiol Biostat 2000; 5:221-31.

17. Leung GM, Woo PP, McGhee SM, Cheung AN, Fan $\mathrm{S}$, Mang O, et al. Age-period-cohort analysis of cervical cancer incidence in Hong Kong from 1972 to 2001 using maximum likelihood and Bayesian methods. J Epidemiol Community Health 2006; 60:712-20.

18. Souza E, Baldwin JR, Rosa FH. A construção social dos papéis sexuais femininos. Psicol Reflex Crit 2000; 13:485-96.

19. Mandú ENT. Trajetória assistencial no âmbito da saúde reprodutiva e sexual: Brasil, século XX. Rev Latinoam Enferm 2002; 10:358-71.

20. Instituto Nacional de Câncer. Câncer no Brasil: dados do registro de base populacional 2008. http:// www.inca.gov.br/regpop/2003/ (accessed on 12/ Jan/2009).
21. Llorca J, Rodriguez-Cundin P, Dierssen-Sotos T, Prieto-Salceda D. Cervical cancer mortality is increasing in Spanish women younger than 50. Cancer Lett 2006; 240:36-40.

22. Silva FCT. Brasil, em direção ao século XXI. In: Linhares MI, organizador. História geral do Brasil. Rio de Janeiro: Editora Elsevier; 2000. p. 385-445.

23. Lago TDG. Políticas nacionais de rastreamento do câncer de colo de útero no Brasil: análise do período 1998 a 2002 [Tese de Doutorado]. Campinas: Universidade Estadual de Campinas; 2004.

24. Ministério da Saúde. Portaria no ${ }^{\circ}$ 3.041, de 21 de junho de 1998. Dispõe sobre a instituição do Comitê Executivo do Programa Nacional de Combate ao Câncer de Colo Uterino. Diário Oficial da União 1998; 6 jul.

25. Costa MR, Marcopito LF. Mortalidade por causas mal definidas, Brasil, 1979-2002, e um modelo preditivo para idade. Cad Saúde Pública 2008; 24: 1001-12.

26. Doll R. Progress against cancer: an epidemiologic assessment. Am J Epidemiol 1991; 134:675-88.

27. Hommel G, Krummenauer F. Improvements and modifications of Tarone's multiple test procedure for discrete data. Biometrics 1998; 54:673-81.

28. Pagano M, Gauvreau K. Testes de hipóteses. In: Pagano M, Gauvreau K, organizadores. Princípios de bioestatística. São Paulo: Editora Pioneira Thomson Learning; 2004. p. 209-31.

Submitted on 07/Nov/2009

Final version resubmitted on 24/Mar/2010

Approved on 05/Apr/2010 